\title{
Bioactive compounds and antioxidant activity three fruit species from the Brazilian Cerrado
}

\author{
Regilda Saraiva dos Reis Moreira-Araújo ${ }^{1}$, Nara Vanessa dos Anjos Barros ${ }^{2}$, \\ Rayssa Gabriela Costa Lima Porto ${ }^{2}$, Amanda de Castro Amorim Serpa Brandão ${ }^{3}$, \\ Alessandro de Lima ${ }^{4}$, Roseane Fett ${ }^{5}$
}

Abstract - The aim of this study was to determine the content of bioactive compounds and antioxidant activity present in three fruit species from the Brazilian Cerrado: carnauba (Copernicia prunifera (Mill.) H.E. Moore), murici (Byrsonima crassifolia L. Rich) and oiti (Licania tomentosa (Benth) Fritsch). Among analyzed fruits, oiti showed the highest total phenolic content (1236.42 $\left.\pm 34.06 \mathrm{mg} \mathrm{GAE} 100 \mathrm{~g}^{-1}\right)$ followed by murici $\left(468.90 \pm 27.30 \mathrm{mg} \mathrm{GAE} 100 \mathrm{~g}^{-1}\right)$ and carnauba (314.44 $\left.\pm 9.50 \mathrm{mg} \mathrm{GAE} 100 \mathrm{~g}^{-1}\right)$. Regarding the antioxidant activity, murici showed $4350.31 \pm$ $1.85 \mu \mathrm{mol}$ TEAC. $100 \mathrm{~g}^{-1}$ and oiti showed $14721.69 \pm 0.85 \mu \mathrm{mol}$ TEAC. $100 \mathrm{~g}^{-1}$. In addition, high content of anthocyanins was verified in carnauba $\left(9.35 \pm 0.00 \mathrm{mg}\right.$-cy-3-glu. $\left.100 \mathrm{~g}^{-1}\right)$, as well as carotenoids $\left(20.0 \pm 1.23 \mathrm{mg}-\beta\right.$-carot. $\left.100 \mathrm{~g}^{-1}\right)$ and vitamin $\mathrm{C}\left(58.60 \pm 1.32 \mathrm{mg} .100 \mathrm{~g}^{-1}\right)$ in murici. In conclusion, data obtained add valuable information to the current knowledge on the nutritional and functional features of fruits from the Brazilian Cerrado that have been scarcely explored, such as those analyzed, which showed high content of bioactive compounds and antioxidant activity. Index Terms: antioxidants, anthocyanins, carotenoids, phenolic compounds, Cerrado.

\section{Compostos bioativos e atividade antioxidante em frutos de três espécies vegetais do Cerrado Brasileiro}

Corresponding author: regilda@ufpi.edu.br

Received: January 17, 2019 Accepted: April 10, 2019

Copyright: All the contents of this journal, except where otherwise noted, is licensed under a Creative Commons Attribution License.
Resumo - Objetivou-se com o presente estudo determinar o teor de compostos bioativos e atividade antioxidante presentes nos frutos de três espécies vegetais do Cerrado Brasileiro: carnaúba (Copernicia prunifera (Mill.) H.E. Moore), murici (Byrsonima crassifolia L. Rich) e oiti (Licania tomentosa (Benth.) Fritsch). Entre os frutos analisados, o fruto oiti apresentou maior conteúdo de fenólicos totais $\left(1236,42 \pm 34,06 \mathrm{mg}\right.$ EAG $\left.100 \mathrm{~g}^{-1}\right)$, seguido do murici $(468,90 \pm 27,30 \mathrm{mg}$ EAG $\left.100 \mathrm{~g}^{-1}\right)$ e do côco da carnaúba $\left(314,44 \pm 9,50 \mathrm{mg}^{2}\right.$ EAG $\left.100 \mathrm{~g} \mathrm{~g}^{-1}\right)$. Quanto à atividade antioxidante, o murici apresentou 4350,31 $\pm 1,85 \mu$ mol TEAC. $100 \mathrm{~g}^{-1}$ e o oiti que apresentou $14721,69 \pm 0,85$ $\mu$ mol TEAC. $100 \mathrm{~g}^{-1}$. Foi verificado também um elevado conteúdo de antocianinas no côco da carnaúba $\left(9,35 \pm 0,00 \mathrm{mg}\right.$-cy-3-glu. $\left.100 \mathrm{~g}^{-1}\right)$ e elevado conteúdo de carotenoides $(20,0 \pm 1,23$ mg- $\beta$-carot. $\left.100 \mathrm{~g}^{-1}\right)$ e vitamina $\mathrm{C}\left(58,60 \pm 1,32 \mathrm{mg} .100 \mathrm{~g}^{-1}\right)$ no murici. Os dados obtidos somam informações ao conhecimento atual sobre as características nutricionais e funcionais de frutos do Cerrado Brasileiro ainda pouco explorados, como os analisados, que apresentaram elevado conteúdo de compostos bioativos e atividade antioxidante.

Termos para indexação: antioxidantes, antocianinas, carotenoides, compostos fenólicos, frutos do Cerrado.

${ }^{1}$ Full Professor of the Department of Nutrition, Federal University of Piauí (UFPI). Minister Petrônio Portella University Campus. Block 13. Teresina-PI. Email: regilda@ufpi.edu.br (ORCID: 0000-0002-3669-2358)

${ }^{2} \mathrm{PhD}$ student of the Graduate Program in Food and Nutrition (PPGAN) / Federal University of Piauí (UFPI). Email: nara.vanessa@hotmail. com (ORCID: 0000-0003-2044-7064); rayssaporto@hotmail.com (ORCID:0000-0002-2899-8509)

${ }^{3}$ Scholarship granted by the National Postdoctoral Program (PNPD) - Coordination for the Improvement of Higher Education Personnel (CAPES) of the Graduate Program in Food and Nutrition (PPGAN) / Federal University of Piauí (UFPI). Email: amandacastronut@yahoo.com.br (ORCID: 0000-0002-1310-3880)

${ }^{4}$ Full Professor of the Federal Institute of Piauí (IFPI). Email: alessandro@ifpi.edu.br (ORCID: 0000-0002-5861-5273)

${ }^{5}$ Full Professor, Department of Food Science and Technology, Federal University of Santa Catarina. Email: roseane.fett@gmail.com (ORCID: 0000-0002-7284-9324) 


\section{Introduction}

Fruits and vegetables contain antioxidants, whose activities have been well documented in recent years. The presence of phenolic compounds such as flavonoids, phenolic acids, anthocyanins, as well as vitamins E, C and carotenoids contributes to the beneficial effects of these foods (BROINIZI et al., 2007).

With more than 40,000 plant species, representing $20 \%$ of the world flora, the Brazilian flora is one of the most diverse in the world. However, plant diversity is far from being optimally exploited, in part due to historical factors, because the Portuguese colonial project disregarded the potential of native products (OLIVEIRA et al., 2012). Currently, Brazil is one of the three largest fruit producers only behind China and India, with production exceeding 40 million tons, due to territorial extension, geographical location and climate and soil conditions. The area occupied by the fruit growing activity totaled 2.5 million hectares in 2016, generating about 6 million direct jobs. The country focuses its production on the domestic market, exporting only about $3 \%$ of the fruit production. In 2016, IBGE estimated that production to 2017 would be approximately 44 million tons (KIST et al., 2018).

Brazil has a large number of native and exotic fruit species as yet unknown or under-exploited species, with potential interest for the agribusiness and possible future source of income for local population (RUFINO et al., 2010; MATTIETTO et al., 2010). Brazilian fruits have been evaluated by numerous studies worldwide aiming to analyze their nutritional value, and especially the characterization of exotic fruits has attracted interest from the scientific community for being major sources of bio substances (ALMEIDA et al., 2011; CARDOSO et al., 2011; CLERICI; CARVALHO-SILVA, 2011; DEMBITSKY et al, 2011; RUFINO et al., 2010).

The increasing world interest for Brazilian fruits has boosted research in the Cerrado, one of the Brazilian biomes that have mostly contributed to the supply of these fruits. The Cerrado biome is the second-largest in South America, occupying an area of 2,036,448 km2, about 22\% of the national territory. Its continuous area includes the States of Goiás, Tocantins, Mato Grosso, Mato Grosso do Sul, Minas Gerais, Bahia, Maranhão, Piauí, Rondônia, Paraná, São Paulo and the Federal District, in addition to stretches in the states of Amapá, Roraima and Amazonas (BRASIL, 2019).

Fruit and vegetable consumption has been linked to lower incidence of mortality from non-communicable chronic diseases. Fruits contain high levels of biologically active components that provide health benefits and basic nutritional compounds. Among biologically active components, natural antioxidants have attracted interest due to their potential therapeutic efficacy and safety, protecting human body against oxidative stress, aiding in the prevention of chronic non- transmitted diseases, such as cancer, cardiovascular and cerebrovascular diseases (CANUTO et al., 2010; RUFINO et al. 2010; ROCHA et al. 2013; AUNE et al. 2017). Antioxidants are any substance that, when present at low concentrations, compared to that of oxidizable substrate, significantly slow or inhibit the oxidation of this substrate. They act by inhibiting and/or decreasing the effects triggered by free radicals, not reactive species derived from the oxygen metabolism. Such actions can be reached through different mechanisms of action: preventing the formation of these radicals (prevention systems), preventing the action of such systems (scanners) or favoring the repair and reconstruction of injured biological structures (repair) (BARBOSA et al., 2010; ROCHA et al. 2013).

Native Brazilian fruits are considered excellent sources of bioactive compounds, such as phenolics and carotenoids (PEREIRA et al., 2013), as well as high in vitro antioxidant activity and significant amounts of flavonoids and vitamin C (GONÇALVES; LAJOLO; GENOVESE, 2010). Despite the significant nutritional and functional value, many fruits from the Brazilian Cerrado remain little known and studied (MORZELLE et al., 2015; ROCHA et al., 2013). Thus, the assessment of the potential benefits of these fruits for human health is of utmost importance because, in addition to bringing to light new species useful for human consumption, encourages consumption and the development of new products, as well as the appreciation of the Cerrado flora.

Copernicia prunifera (carnauba) is a plant belonging to the Arecaceae family, adapted to hot and dry climate and is well known in the Northeastern region of Brazil (Piauí, Maranhão) as carnauba (OLIVEIRA et al., 2014). Fruits are edible, in the glabrous form of a rounded berry around two inches long, greenish, turning to dark purple or almost black in maturation, of sparsely carnosus epicarp, involving a very hard lump, provided with albumen White, hard and oily and the seeds can be extracted oil or be made tea, which can be used as energetic (BEZERRA, 2013).

Byrsonima crassifolia L. Rich (murici) belonging to the Malpighiaceae family, which is known in Brazil as Giladinha-fake, Mirici, Muricizinho, donkey-ear and deer-ear. Murici, B. Crassifolia fruit, is a spherical fruit (1-2 $\mathrm{cm}$ in diameter), which can be consumed fresh, and when ripe presents a strong yellow color and odor similar to that of aged cheese. The pulp is fleshy and soft, being able to be consumed in the form of juices, jams, ice creams and liqueurs (HAMACEK; MARTINO PINHEIROSANT'ANA, 2014).

Licania tomentosa Benth belongs to the Chrysobalanaceae family, order Rosales. In northeastern Brazil, Licania species of are known as oiti. This fruit is 
edible, with seeds rich in oil, a fusiform drupe, or oval fruit, from 12 to $16 \mathrm{~cm}$ in length, wrapped in yellow, sticky and fibrous mass, with yellow peel when ripe (SOUSA et al., 2013).

In addition, many other native species of great economic potential are still restricted only to local and regional markets, or are exploited in an extractivist way or underutilized for human consumption. Studies on the chemical composition and content of bioactive compounds of the three fruit species from the Brazilian Cerrado of this study are very scarce, abd there are no records in food composition tables. Thus, this study aimed to determine the content of bioactive compounds and antioxidant activity of three fruits species from the Brazilian Cerrado: carnauba (Copernicia prunifera), murici (Byrsonima crassifolia L. Rich) and oiti (Licania tomentosa Benth Fritsch).

\section{Material and methods}

Fruits analyzed in the present study were: Coconut of carnauba (Copernicia prunifera), Murici (Byrsonima crassifolia L. Rich) and oiti (Licania tomentosa Benth Fritsch). Fruits were harvested at Embrapa Meio NortePI, located in the city of Teresina, Capital of the state of Piauí, which is in latitude $05^{\circ} 05^{\prime} 21$ ' ' and longitude $42^{\circ} 48^{\prime} 07^{\prime}$ ' . The harvest was carried out taking into consideration standardization in relation to maturation stage, being harvested at the physiologically mature stage, considering size, color and shape of each species, absence of mechanical damage and apparent contaminations on the epidermis of fruits. Thirty fruits of 10 plants were harvested in the second half of 2017. After selection, sodium hypochlorite solution at $100 \mathrm{mg} \mathrm{L}^{-1}$ was performed for 10 minutes, previously acidified with hydrochloric acid $(\mathrm{pH}=3.0)$, with subsequent rinse with distilled water. To obtain pulp, shells, seeds or fruit kernels were removed, which were subsequently liquefied and frozen $\left(-18^{\circ} \mathrm{C}\right)$ until analyses. All analyses of bioactive compounds and determination of the antioxidant activity were performed in triplicate, expressed in fresh weight of fruits carried out in the period of about one week after harvest.

\section{Obtaining and preparing extracts}

Extracts were prepared according to Rufino et al. (2011), with modifications. The solvents used for the extraction of antioxidant compounds were $50 \%$ methanol $(50: 50, \mathrm{~V} / \mathrm{V}), 70 \%$ acetone $(70: 30, \mathrm{~V} / \mathrm{V})$ and water. About 1 to 2 grams of samples were weighed in centrifuge tubes $(50 \mathrm{~mL})$ and bioactive compounds were sequentially extracted with $4 \mathrm{~mL}$ of $50 \%$ methanol for 60 minutes at room temperature. Tubes were centrifuged at $4000 \mathrm{rpm}$ for 15 minutes and the supernatant was collected in a volumetric flask $(10 \mathrm{~mL})$. Then, $4 \mathrm{~mL}$ of $70 \%$ acetone were added to the residue, extracted for 60 minutes and centrifuged again as previously described. The two supernatants obtained were combined in volumetric flask $(10 \mathrm{~mL})$ and the volume was completed with Milli-Q water, thus obtaining extracts to determine the content of total phenolic compounds and antioxidant activity.

\section{Determination of total phenolic compounds}

The content of phenolic compounds in fruits was spectrophotometrically determined using the FolinCiocalteu reagent (SINGLETON; ROSSI, 1965). Two mL of Milli-Q water were added in a $10 \mathrm{~mL}$ flask, $100 \mu \mathrm{L}$ of sample (extract) with automatic pipette and transferred to a $10 \mathrm{~mL}$ volumetric flask. About $0.5 \mathrm{~mL}$ of FolinCiocalteu reagent were added and vigorously stirred. After 5 minutes, $1.5 \mathrm{~mL}$ of $20 \% \mathrm{~m} / \mathrm{V}$ sodium carbonate was added, shaken well and diluted with Milli-Q water until volume was completed to $10 \mathrm{~mL}$. After a 2-hour resting period, the ambient temperature was measured by spectrophotometer absorbance (Shimadzu 02900, Serial № A $114547 / \mathrm{UV}-1,800)$ at $765 \eta \mathrm{m}$ in $10 \mathrm{~mm}$ bucket. The concentration of total phenolics was obtained by interpolating the absorbance in a previously constructed standard galic acid curve. Results were expressed in grams of galic acid equivalents (GAE) by $100 \mathrm{~g}$ of fresh sample.

\section{Determination of the antioxidant activity}

The antioxidant activity of carnauba, murici and oiti fruits was determined by the method of capturing the DPPH radical (2.2-difenyl-1-picrylhydrazyl) developed by Brand-Williams; Cuvelier Berset, (1995). First, $0.0394 \mathrm{~g}$ of the radical was weighed and dissolved in $10 \mathrm{~mL}$ of methanol. After this procedure, 1:100 dilution of the solution was performed in $80 \% \mathrm{v} / \mathrm{V}$ methanol adjusting the initial absorption to 0.800 . In test tubes, 100 $\mu \mathrm{L}$ of extract were added to $2.9 \mathrm{~mL}$ of this solution and homogenized and the mixture was maintained in a dark place at room temperature for 30 minutes. Absorbance measurements were performed in spectrophotometer (Shimadzu 02900, Serial No. A 114547/UV-1,800) at wavelength of $515 \eta \mathrm{m}$, of the radical, before and after adding the sample (with 30 minutes of reaction). A white test with $2.9 \mathrm{~mL}$ DPPH and $100 \mu \mathrm{L}$ of solvent was conducted in parallel. Standard curve with Trolox (6-hydroxy-2, 5, 7, 8-tetramethylchromium-2-carboxylic acid) was constructed at different concentrations (0-100 $\left.\mathrm{mg} \mathrm{L}^{-1}\right)$ as reference. Results were expressed as $\mu \mathrm{mol}$ TEAC (antioxidant capacity equivalent to Trolox) for $100 \mathrm{~g}^{-1}$ sample.

\section{Determination of anthocyanins}

The content of total anthocyanins was determined using the $\mathrm{pH}$ difference method (GIUSTI; WROLSTAD, 2001). About $550 \mu \mathrm{L}$ were collected from the dilute sample and transferred to a test tube, which was added of 
$5 \mathrm{~mL}$ of potassium chloride solution $(\mathrm{KCl} 0,025 \mathrm{M}, \mathrm{pH}$ 1.0), homogenized and stored for $10 \mathrm{~min}$ in the absence of light. The same procedure was repeated for sodium acetate (CH3COONa. 3H20, 0.4 M, pH 4.5). Absorbance was measured at maximum absorption wavelength and in $700 \eta \mathrm{m}$ in spectrophotometer (Shimadzu 02900, Serial No A 114547/UV-1,800). Absorbance was calculated from Equation 1:

$$
\mathrm{A}=\left(\mathrm{A}_{\text {max.vis }}-\mathrm{A}_{700 \eta \mathrm{m}}\right)_{\mathrm{pH} 1,0}-\left(\mathrm{A}_{\text {max.vis }}-\mathrm{A}_{700 \eta \mathrm{m}}\right)_{\mathrm{pH} 4,5}
$$

Since the concentration of monomeric pigments can be calculated and expressed in cyanidine-3-glycoside (PM: 449.2 and $\varepsilon: 26.900)$, the content of monomer anthocyanins (mg. $100 \mathrm{~g}^{-1}$ ) was calculated according to Equation 2:

$$
(\mathrm{A} \times \mathrm{MW} \times \mathrm{DF} \times 100) /(\varepsilon \times 1)
$$

Where: $\mathrm{A}=$ absorbance; $\mathrm{MW}=$ molecular weight; $\mathrm{DF}=$ dilution factor; $\varepsilon=$ Molar absorptivity.

\section{Determination of total carotenoids}

The content of total carotenoids was determined according to methodology of Alvarez-Suarez et al., (2011); Ferreira et al., (2009). $1 \mathrm{~g}$ of sample was weighed in a $30 \mathrm{~mL}$ Becker and $10 \mathrm{~mL}$ of Acetone/hexane $(4: 6 \mathrm{~V} / \mathrm{V})$ solvent were added, which remained under agitation for 10 minutes in magnetic stirrer. After this period, the solution was was filtered and absorbance wasc read in spectrophotometer (Shimadzu 02900, Serial No A 114547/ $\mathrm{UV}-1,800)$ at $450 \eta \mathrm{m}$. Results were expressed in $\mathrm{mg}$ of $\beta$-carotene per $100 \mathrm{~g}$ of sample by comparison with previously elaborated standard $\beta$-carotene curve.

\section{Determination of vitamin C}

The ascorbic acid concentration (vitamin C) was determined by the Tillmans method, which is based on the reduction of 2.6-dichlorophenol sodium indophenol (DCFI) by ascorbic acid, according to Benassi and Antunes (1988).

\section{Data analysis}

For data analysis, a database was elaborated using the SPSS statistical software, version 13. Results were expressed as the average of triplicate and standard deviation. The Tukey average test was applied at 5\% significance level.

\section{Results and discussion}

The results of the determination of bioactive compounds and antioxidant activity in carnauba (Copernicia prunifera), murici (Byrsonima crassifolia L. Rich) and oiti fruits (Licania tomentosa (Benth) Fritsch).) are shown in table 1.

For Rocha et al. (2013), the presence of phenolic compounds in fruits is usually associated with the mechanism of adaptation and resistance of the plant to the environment, and may influence flavor, technological characteristics such as darkening or precipitation during processing, as well as the nutritive and functional potential of fruits. Thus, the knowledge of the contents of these compounds, as well as their antioxidant activity in native fruits is important, because in many cases, as for oiti, data are scarce or inexistent in literature (case of carnauba and murici fruits).

Considering table 1, the fruit that stood out with the highest content of total phenolic compounds was oiti, followed by murici and carnaúba. The results obtained in the present study were higher than those verified by Rocha et al. (2013), who analyzed five other fruits from the Cerrado, obtaining for the ethanolic extract contents of $27.42 ; 85.37 ; 51.15 ; 34,1$ and $60.5 \mathrm{mg} \mathrm{GAE} 100 \mathrm{~g}-^{1}$ for cagaita, chicha, cajuí, jatobá and macaúba fruits, respectively. Results were also higher than those verified by Almeida et al. (2011), who analyzed the content of total phenolics of 11 exotic fruits cultivated in northeastern Brazil and observed levels ranging from $13.5 \mathrm{mg}$ GAE100 $\mathrm{g}^{-1}$ for Sapodilla fruit to $159.9 \mathrm{mg} \mathrm{GAE} 100 \mathrm{~g}^{-1}$ for murici. Oiti can be considered an important source of phenolic compounds, considering that it stood out in comparison with other tropical fruits known for being sources of these compounds, such as camu-camu (1176 mg GAE100 g $\mathrm{g}^{-1}$ ) and acerola (1063 mg GAE $100 \mathrm{~g}^{-1}$ ) (RUFINO et al., 2010).

Rufino et al. (2010) classified fruits into three distinct categories: fruits with low $(<100 \mathrm{mg}$ GAE 100 $\left.\mathrm{g}^{-1}\right)$, intermediate (100-500 mg GAE $\left.100 \mathrm{~g}^{-1}\right)$ high $(>500$ mg GAE $100 \mathrm{~g}^{-1}$ ) content of phenolic compounds in the fresh form. Considering this classification, oiti fruits presented high content of these compounds, while murici and carnauba fruits were classified with intermediate levels of total phenolics. Probably, the high content of phenolic compounds justified its high antioxidant activity $\left(14721.69 \pm 0.85 \mu\right.$ mol TEAC. $\left.100 \mathrm{~g}^{-1}\right)$ expressed by antioxidant activity equivalent to Trolox (standard antioxidant), obtaining high values when compared with carnauba and murici, $2839.59 \pm 52.31$ and $4350.31 \mu \mathrm{mol}$ TEAC $100 \mathrm{~g}^{-1}$, respectively, with statistically significant difference, as can be seen in table 1 .

For carnauba fruits, the results observed in the present study for the total phenolic compounds $(314.44 \mathrm{mg}$ GAE $100 \mathrm{~g}^{-1}$ ) were similar to those of Rufino et al. (2010), 
who obtained $338 \mathrm{mg} \mathrm{GAE} 100 \mathrm{~g}^{-1}$ for aqueous extracts, and higher than those reported by Clerici and CarvalhoSilva (2011) in black berry samples, a recognized source of antioxidant compounds and pigments, ranging from 23.8 to $289,3 \mathrm{mg}$ GAE $100 \mathrm{~g}^{-1}$. However, this study was distinguished by the content of total anthocyanins (9.35 mg-cy-3-Glu. $100 \mathrm{~g}^{-1}$ ) (table 1), which was higher than that obtained by Rufino et al. (2010) in the same fruit (4.1 mg. $\left.100 \mathrm{~g}^{-1}\right)$ and in other tropical fruits such as puçá (3.7 mg. $100 \mathrm{~g} \mathrm{~g}^{-1}$ ), gurguri and cajá, both with $3.3 \mathrm{mg} / 100 \mathrm{~g}$ and bacuri (0.3 mg. $\left.100 \mathrm{~g}^{-1}\right)$. However, in this study, the methodology used for the extraction of anthranic pigments was different from that used in the present research, a fact that makes comparisons difficult.

In murici, the content of phenolic compounds obtained was higher than that observed by Souza et al. (2012) $\left(334,37 \mathrm{mg}\right.$ GAE $\left.100 \mathrm{~g}^{-1}\right)$ and by Almeida et. al. (2011) (159.9 mg GAE $\left.100 \mathrm{~g}^{-1}\right)$. Considering the latter author, the fruit analyzed in the study presented higher content in relation to other Brazilian fruits, such as tamarindo ( $\left.83.8 \mathrm{mg} \mathrm{GAE} 100 \mathrm{~g}^{-1}\right)$, siriguela $(55.0 \mathrm{mg}$

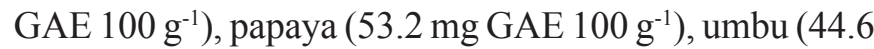
mg GAE $100 \mathrm{~g}^{-1}$ ), pineapple (38.1 mg GAE $\left.100 \mathrm{~g}^{-1}\right)$ and jaca (29.0 mg GAE $\left.100 \mathrm{~g}^{-1}\right)$.

In carnauba and murici fruits, high levels of vitamin C were observed, $78.1 \mathrm{mg} .100 \mathrm{~g}^{-1}$ and $58.6 \mathrm{mg} .100 \mathrm{~g}^{-1}$, respectively, when compared with the recommended daily intake (RDI) for this micronutrient, which is 45 mg (BRAZIL, 2005). Comparing with data obtained by Couto and Canniatti-Brazaca (2010), it was observed that the ascorbic acid content expressed in vitamin $\mathrm{C}$ in these fruits was higher than that of most citrus fruits, with results expressed as ascorbic acid (mg. $100 \mathrm{~mL}-1$ juice): poncã tangerine $32.47 \pm 1.791$ and murcott tangerine $21.47 \pm$ 1.11; and lower than the "pera" orange content $62.50 \pm$ 0.96 , orange-lime $64.58 \pm 0.46$, "natal" orange $84.03 \pm$ 3.18 , "Valencia" orange $78.47 \pm 1.20$ and "baia" orange $80.03 \pm 1.03$. And taking into account the RDI for this micronutrient, both fruits have high content of vitamin $\mathrm{C}$, as they cover the minimum of $30 \%$ of the respective DRI (BRAZIL, 2012).

As for the content of total carotenoids, murici and oiti fruits stood out, with $20.0 \mathrm{mg} \beta$-carotene $/ 100 \mathrm{~g}$ and $2.43 \mathrm{mg} \beta$-carotene $/ 100 \mathrm{~g}$, respectively. This content was higher than those observed for several Brazilian tropical fruits, such as jussara $\left(1.9 \mathrm{mg} .100 \mathrm{~g}^{-1}\right)$, murici $(1.1 \mathrm{mg}$. $\left.100 \mathrm{~g}^{-1}\right)$, umbu $\left(1.0 \mathrm{mg} .100 \mathrm{~g}^{-1}\right)$, caja $\left(0.7 \mathrm{mg} .100 \mathrm{~g}^{-1}\right)$ and cashew (0.4 mg. $100 \mathrm{~g}^{-1}$ ) (RUFINO et al., 2010). In the study by Souza et al. (2012), who evaluated fruits from the Brazilian Cerrado, higher content was observed in fruits analyzed in the present study, compared to marolo $(0.57$ $\mathrm{mg} \beta$-carotene. $\left.100 \mathrm{~g}^{-1}\right)$, murici ( $1.25 \mathrm{mg} \beta$-carotene. 100 $\mathrm{g}^{-1}$ ), Jenipapo (0.93 mg $\beta$-carotene. $100 \mathrm{~g}^{-1}$ ), and sweet passion fruit according to Rodriguez-Amaya et al. (2008), anf for a food to be considered source of carotenoids, it should contain at least $20 \mu \mathrm{g}$. $\mathrm{g}^{-1}\left(2 \mathrm{mg} .100 \mathrm{~g}^{-1}\right)$. Therefore, it could be inferred that murici and oiti fruits can be considered source of these compounds.

Several factors may interfere with the content of bioactive compounds (phenolic compounds, carotenoids and vitamin $\mathrm{C}$ ) in fruits and vegetables, such as genetic factors, differences in agronomic and environmental conditions such as seasonality, temperature, water availability, ultraviolet radiation, nutrient addition, atmospheric pollution, mechanical damage and attack of pathogens. Other secondary factors may interfere with the extraction of these compounds of the food matrix, such as the type of solvent used, degree of polymerization, extraction time and temperature, in addition to interactions with other food constituents (MARATHE et al., 2011; OLIVEIRA et al., 2011). Thus, this could justify the differences observed in the content of these compounds when compared with other studies.

Several studies have shown high correlation between content of phenolic compounds and antioxidant activity (ALMEIDA et al. 2011; CONTRERÁS-CALDERÓN et al. 2010; RAMFUL et al. 2011; RUFINO et al. 2010), and between content of ascorbic acid and antioxidant activity (CONTRERÁS-CALDERÓN et al. 2011; RUFINO et al. 2010). It is important to emphasize that, according to Oliveira et al. (2011), the in vivo antioxidant activity of tropical fruits should be understood as the result of the sum of several bioactive compounds, which reinforces the importance of variety in the composition of meals, and exposes the limitations of propositions that value, more isolate and exclusively, one or another specific food component (1.31 mg $\beta$-carotene. $\left.100 \mathrm{~g}^{-1}\right)$. 
Table 1. Content of bioactive compounds and antioxidant activity in fruits from the Brazilian Cerrado.

\begin{tabular}{|c|c|c|c|}
\hline \multirow{3}{*}{ Bioactive compounds } & \multicolumn{3}{|c|}{ Fruits } \\
\hline & Carnauba & Murici & Oiti \\
\hline & Average \pm SD & Average \pm SD & Average \pm SD \\
\hline Total Phenolics (mg GAE 100-1) & $314.44 \pm 9.50^{\mathrm{a}}$ & $468.90 \pm 27.30^{b}$ & $1236.42 \pm 34.06^{\mathrm{c}}$ \\
\hline Anthocyanins (mgcy-3-glu.100 g $\mathrm{g}^{-1}$ ) & $9.35 \pm 0.00^{\mathrm{a}}$ & $2.04 \pm 0.08^{\mathrm{b}}$ & $2.96 \pm 0.52^{\mathrm{c}}$ \\
\hline Total carotenoids (mg- $\beta$-carot.100g $\mathrm{g}^{-1}$ ) & $0.6 \pm 0.2^{\mathrm{a}}$ & $20.0 \pm 1.23^{\mathrm{b}}$ & $2.43 \pm 0.88^{\mathrm{c}}$ \\
\hline Vitamin C (mg.100-1) & $78.1 \pm 2.6^{\mathrm{a}}$ & $58.60 \pm 1.32^{\mathrm{b}}$ & - \\
\hline \multicolumn{4}{|l|}{ Antioxidant activity } \\
\hline Antioxidant activity $\left(\mu \mathrm{mol}\right.$ TEAC. $\left.100 \mathrm{~g}^{-1}\right)$ & $2839.59 \pm 52.31^{\mathrm{a}}$ & $4350.31 \pm 1.85^{b}$ & $14721.69 \pm 0.85^{\mathrm{c}}$ \\
\hline
\end{tabular}

Caption: (-) determinations not performed. Values presented as mean \pm standard deviation (three replicates per sample). GAE: galic acid equivalent; mgcy-3-Glu: Cyanidin-3-glycoside; mg- $\beta$-Carot: mg $\beta$-carotene.

Different superscript letters between types of fruit show significant difference between the averages according to the Tukey multiple comparison test at $5 \%$ level $(\mathrm{p} \leq 0.05)$ with $95 \%$ confidence ind.

\section{Conclusion}

Based on the results obtained, it was found that among fruits studied, oiti presented the highest content of total phenolics. Carnauba was distinguished by the high content of anthocyanins, murici stood out by the high content of vitamin $\mathrm{C}$, and oiti by the content of carotenoids, when compared with other Brazilian tropical fruits and among themselves. Regarding the antioxidant activity, murici and oiti fruits showed higher values, with statistically significant difference. Therefore, the data obtained add valuable information to the current knowledge about the nutritional and functional characteristics of tropical fruits still poorly explored and/or totally unknown.

\section{Acknowledgements}

The authors are grateful for grants from the National Council of Scientific and Technological Development $(\mathrm{CNPq})$ and to the Coordination for the Improvement of Higher Education Personnel (CAPES) PROCAD/CASADINHO - CNPq-CAPES, Process No. 552239/2011-9 and CNPq Process 482292/2011-3, 431314/2016-0.

\section{References}

ALMEIDA, M.M.B.; SOUZA, P.H.M.; ARRIAGA, A.M.C.; PRADO, G.M.P.; MAGALHÃES, C.E.C.; MAIS, G.A.M. Bioactive compounds and antioxidant activity of fresh exotic fruits from northeastern Brazil. Food Research International, Barking, v.44, p.2155-2159, 2011.

ALVAREZ-SUAREZ, J.M.; TULIPANI, S.; DÍAZ, D.; ESTEVEZ, Y.; ROMANDINI, S.; GIAMPIERI, F.; DAMIANI, E.; ASTOLFI, P.; BOMPADRE, S.; BATTINO, M. Antioxidant and antimicrobial capacity of several monofloral Cuban honeys and their correlation with color, polyphenol content and other chemical compounds. Food and Chemical Toxicology, Oxford, v.48, p.2490-2499, 2011.

AUNE, D.; GIOVANNUCCI, E; BOFFETTA, P.; FADNES, L.T.; KEUM, N.;NORAT, T.; GREENWOOD, D.C.; RIBOLI, E.;VATTEN, L.J.;TONSTAD, S. Fruit and vegetable intake and the risk of cardiovascular disease, total cancer and all cause mortality- a systematic review and dose response meta analysis of prospective studies. International Journal of Epidemiology, Oxford, v.46, n.3, p.1029-1056, 2017.

BARBOSA, K.B.F.; COSTA, N.M.B.; ALFENAS, R.DE C.G.; DE PAULA, S.O.; MININ, V.P.R.E.; BRESSAN, J. Estresse oxidativo: conceito, implicações e fatores modulatórios. Revista de Nutrição, Campinas, v.4, n.23, p.629-643, 2010. 
BENASSI, M.T.; ANTUNES, A.J.A. Comparison of meta-phosphoric and oxalic acids as extractant solutions for the determination of vitamin $\mathrm{C}$ in selected vegetables. Arquivos de Biologia e Tecnologia, Curitiba, v.31, n.4, p.507-513, 1988.

BEZERRA, K.C.B.Características físicas e físicoquímicas do fruto da carnaúba (Copernicia prunifera H.E.MOORE). 2013. Dissertação (Mestrado em Alimentos e Nutrição) - Universidade Federal do Piauí, Teresina, 2013.

BLOIS, M.S. Antioxidant determinations by the use of a stable free radical. Nature, London, n.181, v.1, p.199200, 1958.

BRAND-WILLIAMS, W.; CUVELIER, M.E.; BERSET, C. Use of a free radical method to evaluate antioxidant activity. Lebensmittel-Wissenschaft und-Technologie, London, v.28, n.1, p.25-30, 1995.

BRASIL. Ministério da Saúde. Agência Nacional de Vigilância Sanitária (ANVISA). Resolução RDC n 269 , de 22 de setembro de 2005. Dispõe sobre o regulamento técnico sobre a ingestão diária recomendada (IDR) de proteína, vitaminas. Diário Oficial [da] República Federativa do Brasil. Brasília, 2005. Disponível em: http://e-legis.anvisa.gov.br/leisref/public/showAct. php?id=18828\&word. Acesso em: 12 mai. 2016.

BRASIL. Ministério da Saúde.Agência Nacional de Vigilância Sanitária. Resolução RDC no 54, de 12 de novembro de 2012. Dispõe sobre o Regulamento Técnico sobre Informação Nutricional Complementar. Brasília: Ministério da saúde; 2012. Disponível em: http://s.anvisa. gov.br/wps/s/r/y77. Acesso em: 12 mai. 2016.

BRASIL. Ministério do Meio Ambiente. O Bioma cerrado. Disponível em: http://www.mma.gov.br/biomas/ cerrado. Acesso em: 14 jan. 2019.

BROINIZI, P.R.B. et al. Avaliação da atividade antioxidante dos compostos fenólicos naturalmente presentes em subprodutos do pseudofruto de caju (Anacardium occidentale L.). Ciência e Tecnologia de Alimentos, Campinas, v.27, n.4, p.902-908, 2007.

CANUTO, G.A.B; XAVIER, A.A.O; NEVES, L.C.; BENASSI, M.T. Caracterização físico-química de polpas de frutos da Amazônia e sua correlação com a atividade antirradical livre. Revista Brasileira de Fruticultura, Jaboticabal, v.32, n.4, p.1196-1205, 2010.
CARDOSO, L.M.; MARTINO, H.S.D.; MOREITA, A.V.B.; RIBEIRO, S.M.R.E SANT’ANA, H.M.P. Cagaita (Eugenia dysenterica DC.) of the Cerrado of Minas Gerais, Brazil: Physical and chemical characterization, carotenoids and vitamins. Food Reasearch International, Barking, v.44, p.2151-2154, 2011.

CLERICI, M.T.P.S.; CARVALHO-SILVA, L.B. Nutritional bioactive compounds and technological aspects of minor fruits grown in Brazil. Food Research International, Barking, v.44, p.1658-1670, 2011.

CONTRERAS-CALDERÓN, J.; CALDERÓNJAIMES, L.; GUERRA-HERNÁNDEZ, E.; GARCÍAVILLANOVA, B. Antioxidant capacity, phenolic content and vitamin $C$ in pulp, peel and seed from exotic fruits from Colombia. Food Research International, Barking, v.44, p.2047-2053, 2011.

COUTO, M.A.L; CANNIATTI-BRAZACA, S.G. Quantificação de vitamina $C$ e capacidade antioxidante de variedades cítricas. Ciências e Tecnologia de Alimentos, Campinas, v.30, p.15- 19, 2010.

DEMBITSKY, V.M.; POOVARODOM, S.; LEONTOWICZ, H.; LEONTOWICZ, M.; VEARASILP, S.; TRAKHTENBERG, S. The multiple nutrition porpeerties of some exotic fruits: Biological activity and active metabolites. Food Research International, Barking, v.44, p.1671-1701, 2011.

FERREIRA, I.C.F.R.; BARROS, L.E ABREU, R.M.V. Antioxidants in wild mush rooms.Current Medicine Chemistry, Cambridge, v.16, p.1543 -1560, 2009.

GIUSTI, M.M.; WROLSTAD, R.E. Anthocyanins. Characterization and measurement with UV-Visible Spectroscopy. In: WROLSTAD, R.E. (ed.). Current protocols in food analytical chemistry. New York: John Wiley \& Sons, 2001. Unit.F1.2.1-13.

GONÇALVES, A.E.S.S.; LAJOLO, F.M.; GENOVESE, M.I. Chemical composition and antioxidant/antidiabetic potential of brazilian native fruits and commercial frozen pulps. Journal of Agricultural and Food Chemistry, Easton, v.58, n.8, p.4666-4674, 2010.

HAMACEK, F.R.; MARTINO, H.S.D.; PINHEIROSANT'ANA, H.M. Murici, fruit from the cerrado of Minas Gerais, Brazil: physical and physicochemical characteristics, and occurrence and concentration of carotenoids and vitamins. Fruits, Paris, v.69, n.6, p.459472, 2014 . 
KIST, B.B.; CARVALHO, C.; TREICHEL, M.; SANTOS, C.E. Anuário brasileiro da fruticultura 2018. Santa Cruz do Sul: Editora Gazeta Santa Cruz, 2018. 88 p. 2018.

LIMA, A.; SILVA, A.M. de O.E.; TRINDADE, R.A.; TORRES, R.P.; MANCINI-FILHO, J. Composição química e compostos bioativos presentes na polpa e na amêndoa do pequi (Caryocar brasiliense, Camb.). Revista Brasileira de Fruticultura, Jaboticabal, v.29, n.3, p.155159.2007.

MARATHE, S.A.; RAJALAKSHMI, V.; JAMDAR, S.N.; SHARMA, A. Comparative study on antioxidant activity of different varieties of commonly consumed legumes in India. Food and Chemical Toxicology, Oxford, v.49, n.9, p.2005-2011, 2011.

MATTIETTO, R.A.; LOPES, A.S.E.; MENEZES, H.C. Caracterização física e físico-química dos frutos da cajazeira (Spondias mombin L.) e de duas polpas obtidas por dois tipos de extrator. Brazilian Journal of Food Tchnolology, Campinas, v.13, p.156-164, 2010.

MORZELLE, M.C.; BACHIEGA, P.; SOUZA, E.C.; BOAS, E.V.B.V.; LAMOUNIER, M.L. Caracterização química e física de frutos de curriola, gabiroba e murici provenientes do Cerrado Brasileiro. Revista Brasileira de Fruticultura, Jaboticabal, v.37, n.1, p.96-103, 2015.

OLIVEIRA, D.DA S.; AQUINO, P.P.; RIBEIRO, S.M.R.; PROENÇA, R.P.DA C.E PINHEIRO-SANT'ANA, H.M. Vitamina $\mathrm{C}$, carotenoides, fenólicos totais e atividade antioxidante de goiaba, manga e mamão procedentes da Ceasa do Estado de Minas Gerais. Acta Scientiarum Health Sciences, Maringá, v.33, p.89-98, 2011.

OLIVEIRA, G.L.S.; JÚNIOR, A.L.G.; OLIVEIRA, F.R.A.M.; FREITAS, R.M. Avaliação da capacidade antioxidante in vitro e in vivo do extrato etanólico da Copernicia prunifera (Mill.) H.E.Moore. Revista de Ciências Farmacêuticas Básica e Aplicada, Araraquara, v.35, n.2, p.293-300, 2014

OLIVEIRA, V.B.; YAMADA, L.T.; FAGG, C.W.; BRANDÃO, M.G.L. Native foods from Brazilian biodiversity as a source of bioactive compounds. Food Research International, Barking, v.48, p.170-179, 2012

PEREIRA, M.C.; STEFFENS, R.S.; JABLONSKI, A.; HERTZ, P.F.; RIOS, A.O.; VIZZOTTO, M.; FLÔRES, S.H. Characterization, bioactive compounds and antioxidant potential of three Brazilian fruits. Journal of Food Composition and Analysis, San Diego, v.13, p.19-24, 2013.
RAMFUL, D.; TARNUS, E.; ARUOMA, O.I.; BOURDON, E.; BAHORUN, T. Polyphenol composition, vitamin $\mathrm{C}$ content and antioxidant capacity of Mauritian citrus fruit pulps. Food Research International, Barking, v.44, p.2088-2099, 2011.

ROCHA, M.S.; FIGUEIREDO, R.W.; ARAÚJO, M.A.M.E MOREIRA-ARAÚJO, R.S.R. Caracterização fisico-química e atividade antioxidante (in vitro) de frutos do Cerrado piauiense. Revista Brasileira de Fruticultura, Jaboticabal, v.35, n.4, p.933-941, 2013.

RODRIGUEZ-AMAYA, D.B.; KIMURA, M.; GODOY, H.T.; AMAYAFARFAN, J. Updated Brazilian on food carotenoids: factors affecting carotenoid composition. Journal of Food Composition and Analysis, San Diego, v.21, p.445-463, 2008.

RUFINO, M.S.M.; ALVES, R.E.; BRITO, E.S.; JIMÉNEZ, J.P.; CALIXTO, F.S.E FILHO, J.M. Bioactive compounds and antioxidant capacities of 18 non-traditional tropical fruits from Brazil. Food Chemistry, London, v.121, p.996-1022, 2010.

RUFINO, M.S.M.; ALVES, R.E.; FERANDES, F.A.N.; BRITO, E.S. Free radical scavenging behavior of ten exotic tropical fruits extracts. Food Research International, Barking, v.44, p.2072-2075, 2011.

SINGLETON, V. L.; ROSSI, J.A. Colorimetry of total phenolics with phosphomolybdic phosphotungstic acid reagents. American Journal Enology and Viticulture, Davis, v.16, n.3, p.144-168, 1965.

SOUSA, E.P.; SILVA, L.M.M.; SOUSA, F.C.; MARTINS, J.J.A.; GOMES, J.P. Características físicas e físicoquímica dos frutos de oiti. Tecnologia \& Ciência Agropecuária, João Pessoa, v.7, p.39-43, 2013. Número Especial

SOUZA, V.R.; PEREIRA, P.A.P.; QUEIROZ, F.; BORGES, S.V.; CARNEIRO, J.D.S. Determination of bioactive compounds, antioxidant activity and chemical composition of Cerrado Brazilian fruits. Food Chemistry, London, v.134, p.381-386, 2012. 